Hydrol. Earth Syst. Sci., 17, 2459-2472, 2013

www.hydrol-earth-syst-sci.net/17/2459/2013/

doi:10.5194/hess-17-2459-2013

(C) Author(s) 2013. CC Attribution 3.0 License.

\title{
Water Accounting Plus (WA+) - a water accounting procedure for complex river basins based on satellite measurements
}

\author{
P. Karimi ${ }^{1,2}$, W. G. M. Bastiaanssen ${ }^{2,3}$, and D. Molden ${ }^{4}$ \\ ${ }^{1}$ International Water Management Institute, Battaramulla, Sri Lanka \\ ${ }^{2}$ Faculty of Civil Engineering and Geosciences, Water Management Department, Delft University of Technology, \\ Delft, The Netherlands \\ ${ }^{3}$ eLEAF Competence Centre, Wageningen, The Netherlands \\ ${ }^{4}$ International Centre for Integrated Mountain Development, Kathmandu, Nepal
}

Correspondence to: P. Karimi (p.karimi@cgiar.org, p.karimi@tudelft.nl)

Received: 25 October 2012 - Published in Hydrol. Earth Syst. Sci. Discuss.: 13 November 2012

Revised: 11 March 2013 - Accepted: 13 March 2013 - Published: 4 July 2013

\begin{abstract}
Coping with water scarcity and growing competition for water among different sectors requires proper water management strategies and decision processes. A prerequisite is a clear understanding of the basin hydrological processes, manageable and unmanageable water flows, the interaction with land use and opportunities to mitigate the negative effects and increase the benefits of water depletion on society. Currently, water professionals do not have a common framework that links depletion to user groups of water and their benefits. The absence of a standard hydrological and water management summary is causing confusion and wrong decisions. The non-availability of water flow data is one of the underpinning reasons for not having operational water accounting systems for river basins in place. In this paper, we introduce Water Accounting Plus (WA+), which is a new framework designed to provide explicit spatial information on water depletion and net withdrawal processes in complex river basins. The influence of land use and landscape evapotranspiration on the water cycle is described explicitly by defining land use groups with common characteristics. $\mathrm{WA}+$ presents four sheets including (i) a resource base sheet, (ii) an evapotranspiration sheet, (iii) a productivity sheet, and (iv) a withdrawal sheet. Every sheet encompasses a set of indicators that summarise the overall water resources situation. The impact of external (e.g., climate change) and internal influences (e.g., infrastructure building) can be estimated by studying the changes in these WA+ indicators. Satellite measurements can be used to acquire a vast amount of required
\end{abstract}

data but is not a precondition for implementing WA+ framework. Data from hydrological models and water allocation models can also be used as inputs to WA+.

\section{Introduction}

Over the last $50 \mathrm{yr}$ the world has changed from a situation of an abundance of water to a situation of water scarcity. Over 1.2 billion people live in basins where water demand is reaching, or has exceeded limits of sustainable use (Gleick, 2000; Molden, 2007; Rockström et al., 2009; World Health Organization (http://www.who.int/water_sanitation health/hygiene/en/)). Population growth, changing diets, and economic growth, are some of the main causes of increased water use, which has resulted in competition for water, closed basins (a basin where all available water is depleted), overexploited groundwater resources, degraded land, reduced ecosystem services and anthropologically induced droughts. People have been quite proficient in changing land and water management practices and in modifying river flows to exploit water, also from aquifers. However, the era has now arrived that we need to communicate multi-sectorally for developing joint visions and targets for sustainable water and environmental management.

Our water institutions have been less effective in managing water in this relatively new era of scarcity, and this leads to a decline in the per capita water availability in various 
water-stressed river basins that are often located in arid climates (Alcamo et al., 2007; Molden, 2007; UN-Water, 2007; van der Zaag et al., 2010; Vorosmarty et al., 2000; Wallace, 2000). While the emphasis in the 20th century was on water resources development, there needs to be a shift to improved water management practices to meet the demands of a changing world in the 21 st century. Clearly one obstacle for improved water management is the lack of standard data collection processes. Interpretation of water resources data and communication to a diverging group of water professionals is generally also inadequate. Management of complex river basins involves hydrologists, climatologists, water managers, engineers, policy decision makers, economists, environmentalists, agronomists, anthropologists and lawyers among others; all from different backgrounds, cultures, and education levels. Obviously, this leads to misconceptions and misinterpretations (Perry, 2007), which are not favourable for improving management of the scarce water resources. Terms such as "irrigation efficiency", "water use efficiency" and "water productivity" are often used interchangeably while their intended purposes are rather different. The term "water use" is not unambiguous and can for instance be interpreted as being a "withdrawal" from a water system, "site specific flow" or "consumptive use". Reduction of "water supply" is often confused with "reduction of consumptive use". Such confusion in terminology can have severe consequences for downstream water availability and may even lead to exacerbation of water scarcity (e.g., de Vries et al., 2010). For this reason, Seckler (1996) remarked that it is better to refer to "real water savings". Groundwater abstraction, groundwater depletion and groundwater draft are also terms which are confused and leading to underestimation of the over-exploitation of aquifers. The declining trend of available water per capita is often used, but rarely defined to which flow it relates to. The same holds true for water use in the agricultural sector. These definitions need more rigor.

Investment in water resources management can be more effective with good and appropriate data being available and if the management options are commonly understood, accessible, acceptable and agreed upon by various stakeholders. The data source underpinning the presentation of water resources conditions and management should be described, and the error sources should be understood. This calls for an appropriate framework for planning, operation, monitoring and evaluation of water resources in river basins. Very often the existing analytical frameworks consider one water use sector only (i.e., drinking water supply sector), focus on one aspect of water management (i.e., gross withdrawals), or are based on one particular hydrological processes (i.e., rainfall and surface runoff relationships) without any attempt to link these processes.

Water accounting integrates the fields of hydrology, water and environmental management, water allocations, reporting and communication, and policy decisions. It facilitates identification of central problems in river basins, constraints and opportunities for improved climate resilience; it assists with decisions regarding carbon sequestration and safeguarding sufficient water resources for a good quality life, also during periods of prolonged drought. Water accounting is described in this context below.

This paper introduces a simple, understandable and standardised way of describing the overall land and water management situation in complex river basins. Ideally, complex conditions should be summarised on a few pages with tables and graphs. It is a challenge to present integrated water resources management issues in both a simplistic and sufficiently comprehensive way. For some it will always be oversimplified, while other water professionals prefer a simplified version. The benefit of having a standard analytical framework and associated terminology has been demonstrated by FAO in the field of evapotranspiration. The FAO standardisation of reference evapotranspiration ET (Allen et al., 1998) has for instance been widely adopted by the international community of agricultural and irrigation engineers to describe ET processes and get global uniformity in crop and irrigation water requirement computations. Similarly, a standard water accounting procedure could facilitate the description of the state conditions of river basins and the opportunities to exploit manageable water flows more effectively, efficiently, productively and sustainably.

The objective of this paper is to introduce a new water accounting framework that is called Water Accounting Plus (WA+). The framework can be filled with satellite data that are freely available in Data Active Archives. WA+ is based on the early definitions introduced by the International Water Management Institute (Molden, 1997). The objective of WA + is to make water accounting easier to use in terms of available input data, and to help improve strategic decisions in water resources management. The companion paper (Karimi et al., 2013) describes the application of the WA+ in the Indus basin.

\section{Brief review of water accounting frameworks}

The importance of reporting on water has motivated several national and international organisations like the UN, FAO, IWMI and the Australian government to develop standard water accounting frameworks. Food and Agriculture Organization's (FAO) global information system on water and agriculture, Aquastat, remains an important source of data, and has the advantage of consistency and standard terminology. However, Aquastat falls short of giving enough detail about the interaction between land use and water use. One major point pertinent to water scarce basins is that Aquastat focuses on water withdrawals, and does not distinguish between consumptive use (i.e., ET) and non-consumptive use (i.e., return flows). The United Nations Statistics Division has proposed a water accounting framework called System of Environmental Economic Accounting for Water (SEEAW). SEEAW 
describes hydrological and economic information through a set of standard tables and has also some supplementary tables to cover social aspects (UN, 2007). The SEEAW accounting includes precipitation, soil water and refers to natural evapotranspiration as one cause of decreasing water stocks. The SEEAW separates consumptive use from non-consumptive use, thus, allows for a wider range of water resources and uses to be included. The SEEAW approach provides comprehensive flow accounting and a well-documented way of presenting links to non-agricultural elements of the economy. However, its applicability for water stock accounting is in question mainly because key required data are unlikely to be available (Perry, 2012). The SEEAW as suggested by Perry (2012) should be expanded to accommodate natural landscape and agriculture, which are typically the major water users in river basins. The SEEAW, for example, describes water input from precipitation, and total evapotranspiration, but does not describe rainfall partitioning through the different water uses and evapotranspiration pathways characterised by different land use classes and the benefits that result from that. The essential difference in green and blue water resources (Falkenmark and Rockström, 2006; Rockström and Gordon, 2001) is not recognised in the SEEAW framework.

The Australian water accounting system is based on SEEAW guidelines (ABS, 2004, 2006) with run-off as the first descriptor. Compared to rainfall and evapotranspiration, flow in streams and rivers represent only a small fraction of the total water movement in semi-arid basins (Molle and Wester, 2009; Sivapalan et al., 2003). The framework accounts for water withdrawals rather than consumptive use. It ignores the essence of consumed water being a sink of the water in the land hydrological system. The Australian method considers irrigated agriculture, industrial and domestic users and does not provide any information on rainfed systems. Thus, the impact of rainfed ecosystems on volumes of water available for irrigation is not addressed. The new Australian water accounting standard (Water accounting standard, 2010) provides a more comprehensive flow accounting and discloses information about the total water resource, the volume of water available for withdrawal, the rights to abstract water, and the actual withdrawals of water for economic, social, cultural and environmental benefit, for geographic regions of national significance. However, similar to the earlier Australian water accounting method, neither rain nor natural ET processes are covered in the accounting.

Perry (2007) proposed a framework for water accounting which divides withdrawals into consumed and nonconsumed fractions of water. The consumed fraction is ET and like in the IWMI water accounting framework published by Molden (1997), it is divided into beneficial and nonbeneficial consumption. The non-consumed fraction is considered as return flows which could be recoverable or nonrecoverable. The latter being the water that is not available for further use like flows to saline groundwater aquifers. Foster and Perry (2010) suggested refinement of soil-water accounting into recover able and non-recoverable water pathways in order to account for the effects of changes in irrigation practices on groundwater recharge. Perry and Bucknall (2009) proposed that basin water balances can be structured on the same approach by including rainfall and inflows as sources and classify uses as beneficial/non-beneficial, recoverable/non-recoverable flows and by dividing water accounts into different end-use classes.

The International Water Management Institute (IWMI) developed a Water Accounting (WA) procedure with the aim of tracking water depletion rather than withdrawals to avoid errors when neglecting recycling, and to account for evapotranspiration. The method provides a means to determine the output per unit of water effectively depleted (Molden, 1997; Molden and Sakthivadivel, 1999; Molden et al., 2003) without a need to account for all the flows related to these processes. The depletion of water resources renders water unavailable for further use. Water depletions are divided into beneficial and non-beneficial water according to the type of use. The IWMI WA framework has been applied by IWMI in many irrigation system studies (e.g., Bhakra system in India: Molden, 1997; Zhanghe Irrigation System in China: Dong et al., 2004; Loeve et al., 2004; Nile Delta: Molden et al., 1998). It has also been used to produce water accounts at river basin scale (e.g., Krishna: Biggs et al., 2007; Karkheh: Karimi et al., 2012; Indrawatti: Bhattarai et al., 2002) and at the national scale (e.g., India: Amarasinghe et al., 2007; Sri Lanka: Bastiaanssen and Chandrapala, 2003).

The IWMI WA framework was originally designed for irrigation schemes within a basin, but was later used for basin analysis. Some of the components of the IWMI WA are, therefore, too generic for basin level studies. For instance, water depletion at irrigation service scale represents only crop evapotranspiration while at basin scale it includes also municipalities, industries, fisheries, forestry, dedicated wetlands and all other uses. As a result, parts of the information that are important in a basin context are not covered in the original IWMI framework.

\section{Water accounting plus (WA+)}

\subsection{Withdrawals, ET and return flow}

Water Accounting Plus (WA+) is a new framework that uses the IWMI WA principles of tracking water depletions rather than withdrawals. WA+ adopts the same definition for water depletion as the IWMI WA, but considers more details in the processes and essential mechanisms. In line with IWMI WA, we use the term depletion hereafter because water consumption in non-agricultural sectors is often associated with withdrawals. FAO (2012) and the International Commission on Irrigation and Drainage, ICID (Perry, 2007) are using consumptive use for crop ET. Depletion in WA+ includes ET and flow to sinks. 


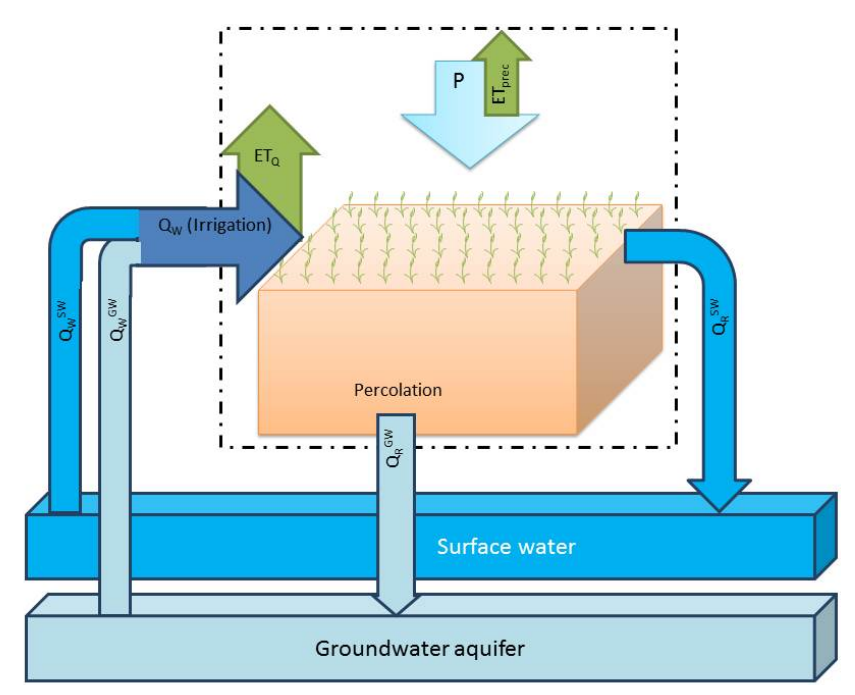

Fig. 1. Basic diagram explaining fundamental differences between gross and net withdrawals in relation to incremental ET.

Datasets on withdrawals and return flows are scarce and incomplete both at the river basin scale, as well as locally by certain water use sectors. Advances in earth observations have, however, demonstrated that ET can be acquired from satellite measurements (e.g., Anderson et al., 2012). By exploring the spatial data on ET, WA+ provides explicit information on water depletion processes for every land use class. WA+ is based on a mass water balance approach. The basis of this water balance approach is that outflow from a certain area of interest (e.g., river basin) are explicitly related to the net inflow and depletion through a measurable ET processes. Therefore, the advantage is that withdrawals and return flows are no longer necessary to be measured because the depletion can be obtained directly from satellite measurements.

The total water balance in a basin in a given time period can be expressed as:

$P+\left(Q_{\mathrm{in}}^{\mathrm{SW}}+Q_{\mathrm{in}}^{\mathrm{GW}}\right)-\mathrm{ET}-\left(Q_{\mathrm{out}}^{\mathrm{SW}}+Q_{\mathrm{out}}^{\mathrm{GW}}\right)+\Delta S=0$

Where $P$ is precipitation, $\left(Q_{\mathrm{in}}^{\mathrm{SW}}+Q_{\mathrm{in}}^{\mathrm{GW}}\right)$ is surface and groundwater inflows to the basin, $\left(Q_{\mathrm{out}}^{\mathrm{SW}}+Q_{\mathrm{out}}^{\mathrm{GW}}\right)$ is surface water and groundwater outflow, and $\Delta S$ is storage change.

Storage change is further divided to:

$\Delta S=\Delta S_{\mathrm{f},}^{\mathrm{SW}}+\Delta S_{\mathrm{f},}^{\mathrm{SM}}+\Delta S_{\mathrm{f},}^{\mathrm{GW}}+\Delta S_{\mathrm{P}}$

Where $\Delta S_{\mathrm{f},}^{\mathrm{SW}}, \Delta S_{\mathrm{f},}^{\mathrm{SM}}$, and $\Delta S_{\mathrm{f},}^{\mathrm{GW}}$ are change in fresh water storage of surface water, groundwater, and snow and glacier melt, respectively. $\Delta S_{\mathrm{P}}$ is change in polluted water storage.

At one single unit in the managed water use group, where withdrawals exist, the water balance equation can be defined as (see Fig. 1):

$P+\left(Q_{\mathrm{w}}^{\mathrm{SW}}+Q_{\mathrm{w}}^{\mathrm{GW}}\right)-\left(\mathrm{ET}_{\text {prec }}+\mathrm{ET}_{\mathrm{Q}}\right)-\left(Q_{\mathrm{R}}^{\mathrm{SW}}+Q_{\mathrm{R}}^{\mathrm{GW}}\right)=0$
Where $\left(Q_{\mathrm{w}}^{\mathrm{SW}}+Q_{\mathrm{w}}^{\mathrm{GW}}\right)$ is withdrawals from surface water and groundwater, $\mathrm{ET}_{\mathrm{prec}}$ is the $\mathrm{ET}$ from precipitation, $\mathrm{ET}_{\mathrm{Q}}$ is the "incremental ET", and $\left(Q_{\mathrm{R}}^{\mathrm{SW}}+Q_{\mathrm{R}}^{\mathrm{GW}}\right)$ is return flow to surface water and groundwater. Incremental $\mathrm{ET}\left(\mathrm{ET}_{\mathrm{Q}}\right)$ is related to withdrawals only. It is the difference between withdrawals and return flows that originate from these withdrawals and water that is incorporated into a product (e.g., incorporation of water into plant tissues). ET from precipitation $\left(\mathrm{ET}_{\mathrm{prec}}\right)$ can be described as:

$\mathrm{ET}_{\text {prec }}=P-Q_{\mathrm{R}_{\text {prec }}}$

Where $Q_{\mathrm{R}_{\text {prec }}}$ is the return flow from rainfall. Return flow consist of water that originates directly from precipitation after partitioning $\left(Q_{\mathrm{R}_{\text {prec }}}\right)$ and return flows from uses of water $\left(Q_{\mathrm{Rw}}\right)$ (e.g., return flows from irrigated fields, sewer outfalls, overflowing canals, drains, etc.). Hence, the return flow $Q_{\mathrm{R}_{\text {prec }}}$ is composed of surface runoff, lateral subsurface drainage and deep percolation from rainfall only. One method to calculate $\mathrm{ET}_{\text {prec }}$ is through existing empirical equations for effective rainfall (e.g., USDA, FAO). These methods estimate the remaining rainwater in the root zone that can be used by plants after deep percolation and runoff. Factors such as the climate, the soil texture, the soil structure and the depth of the root zone influence effective rainfall. The key point is that $\mathrm{ET}_{\mathrm{Q}}$ can be determined as $\mathrm{ET}$ minus $\mathrm{ET}_{\text {prec }}$, without any flow measurements on $\mathrm{QW}_{\mathrm{w}}$ and $\mathrm{Q}_{\mathrm{R}}$ (not further demonstrated in this paper). Spatially distributed data on $\mathrm{ET}_{\mathrm{Q}}$ is useful in ungauged (sub-) basins where withdrawals occur. Water depletion from natural processes and incremental ET can be tracked via spatial ET information for every discrete area, and for every land use class and water user. This concept has been adopted by the WA+ framework to estimate water depletion in different land use management categories.

WA + contains four sheets that summarise the water management situation in complex river basins in an understandable manner. The purpose of each sheet is summarised in Table 1.

The main differences between the IWMI WA from 1997 and the WA+ are the following:

- The link between land use and ET is made explicit in order to understand the impact of land use changes on exploitable water resources.

- Manageable and non-manageable depletions are defined and the processes are quantified, which will show that large volumes of water naturally respond to geographical and atmospheric processes that cannot be managed.

- Surface and groundwater systems are differentiated as they have different management options and legal regulations.

- Incremental ET are computed for different land use categories and water user groups to assign benefits from managed water use. 
Table 1. The purpose of WA+ sheets.

\begin{tabular}{lll}
\hline Water sheets & Purpose & Bookkeeping sheets \\
\hline Resource Base & $\begin{array}{l}\text { Hydrological, manageable, utilisable } \\
\text { flows, water security, sustainability }\end{array}$ & Assets \& liabilities \\
\hline Evapotranspiration & Beneficial \& non-beneficial flows & Profit \& loss/expenditure sheet \\
\hline Productivity & $\begin{array}{l}\text { Biomass returns, carbon sequestration, } \\
\text { food security }\end{array}$ & Profit \\
\hline Withdrawal & Management, regulations, allocations & Cash book \\
\hline
\end{tabular}

- Partitioning of consumed water (ET) into transpiration, evaporation and interception to appraise beneficial ET for food and ecosystem services vs. non-beneficial ET.

- Input data for WA+ can be guaranteed by using satellite measurements so that dependence on local agencies does no longer hold, and data collection systems become standard and transparent. It opens the door for applying WA+ at international basins level, also in conflict areas. However, use of space born data has its own limitations which will be discussed further in details in this paper (Sect. 6).

\subsection{Role of land use categories in WA+}

The total basin water resources consist of rainfall, inflow across water divides and storage changes in surface water, ground water (including soil moisture) and snow water. Only a fraction of the total basin water resources can be controlled and regulated by means of barrier dams, infiltration dams, diversion weirs, inlet points and water harvesting facilities, to create $\mathrm{ET}_{\mathrm{Q}}$ that otherwise would not occur. Land use change (e.g., urban expansion, land reclamation, deforestation) and land cultivation practices (land preparation, crop sowing date, zero tillage) have a regulating affect on $\mathrm{ET}_{\text {prec }}$. Hence land use, cultivation practices and water resources development are controlling factors of ET at the basin scale. Regulation of ET in areas with a high degree of natural land cover such as savannah and mountains is very limited and largely dependent on natural ecosystem processes (e.g., grazing). Consequently, not all land use classes and their associated water flows can be controlled.

Water management practices are commonly focused on those water resources that can be controlled. Influencing the disposition of water through changes in managing land use is less common, but essential to address the growing water scarcity of the future. The WA + framework encompasses four accounting sheets that each reveals specific insights into how water is used. For the sake of simplicity, the hydrological summary can be portrayed on a single page "resource base sheet". The second component is to describe the water depletion (presented on an "Evapotranspiration sheet"), and the third component is to estimate the biomass services and benefits (presented on a "productivity sheet"). The fourth component of WA+ is the quantification of the gross and net withdrawals via the "withdrawals sheet". Presented information in every sheet is linked to a set of standard indicators that help to improve understanding of the basin water resources and conditions, and water management achievements.

To address the role of land use changes and land use planning in the water accounting scheme, we propose to present four different categories of land use groups, based on the potential to manage the land and water resources. These categories include managed water use, modified land use, utilised land use, and conserved land use.

The group "managed water use" represents the land use classes in which the natural water cycle is manipulated by physical infrastructure; water is intentionally retained, withdrawn, pumped, diverted and spilled by pumping stations, valves, pipes, dams, weirs, gates, canals, sluices, culverts and drains for certain objectives. Examples are drinking water supply schemes, irrigation systems, storage for hydropower, maintaining water levels for navigation, flood storage in wetlands, etc. The group "managed water use" includes domestic water use in urban areas and villages, irrigated agriculture, expanding industries for economic development and golf courses (see Table 2 for a more comprehensive overview).

The group "modified land use" refers to land that is significantly modified by human activity for the sake of food, feed, fibre, (bio-)fuels, and fish production. It also includes improved road networks to connect growing populations, dump sites and increasing space for leisure and for socioeconomic growth in the most general terms. Water diversions and withdrawals do not take place in the "modified land use" group, but by modifying vegetation density, hydrological processes such as ET, drainage, percolation, and recharge are affected. Changes in ET in the "modified land use" class can have significant impact on groundwater levels, streamflow, and downstream water availability. Rainfed cropping systems, deforestation, creation of plantation forests, establishment of lanes and parks, home gardens and wind shelters typically fall in the "modified land use" class.

The group "utilised land use" represents a land use that provides a range of ecosystem services and which has had little interference by man. However, people often use such 
land for the services it provides, like food production or fuelwood and nomads on natural pastures. Examples include grassland or savanna (for grazing or wood) and forest land (for timber). This group is typically eligible for carbon credits. Returns from "utilised land use" are often expressed in terms of livestock, wildlife, aquatic birds, fuelwood, oil and minerals. Groundwater dependent ecosystems are also part of this group as well as alien invasive species because invasion is unintentional by humans.

The group "conserved land use" represents areas set aside for minimal disturbance by humans. It includes natural ecosystems or biomes earmarked for conservation and coastal protection. Examples are national parks, coastal dunes, game reserves, glaciers and Ramsar sites.

Table 2 shows the association between land use classes and the four land use groups identified for water accounting. A distinction between land use and land cover is essential in this context. Global land cover databases are available (e.g., GLC2000 by Loveland et al., 2000; Globcover by Bicheron et al., 2006), but do not provide information on usage. Land use databases with particular functions have been produced locally (e.g., Indus Basin: Cheema and Bastiaanssen, 2010), but do not yet provide systematic cover for river basins. Ideally, the land use classes specified in Table 2 should, for water accounting purposes, be created from satellite databases.

\section{The WA+ analytical framework}

\subsection{WA+ resource base sheet}

The WA+ resource base sheet (Fig. 2) provides information on water volumes. Inflows are shown on the left of the resource base sheet diagram, the middle part provides information on how and through what processes the water is depleted within a domain, and information on exploitable water and reports on outflows are summarised on the right.

Precipitation plus any surface or groundwater that flows to the domain from outside its boundaries is Gross inflow. Net inflow includes water storage changes over the period of accounting. The fresh water storage changes are (i) surface water $\left(\Delta S_{\mathrm{f}, \mathrm{SW}}\right)$, (ii) groundwater including soil moisture storage change $\left(\Delta S_{\mathrm{f}, \mathrm{GW}}\right)$ in the vadose zone and (iii) snow and glacier melt $\left(\Delta S_{\mathrm{f}, \mathrm{SM}}\right)$. The net inflow is partitioned into landscape ET and exploitable water present in streams, soils and aquifers. The landscape ET is a consequence of a certain rainfall distribution across a composite terrain with mixed land use, geological formations, soil types, slopes, elevations and natural drainage to streams. Falkenmark and Rockström (2006) defined this as green water. This evaporated water is accounted as being consumed and not available for downstream withdrawals and water resources development, unless moisture recycling through the atmosphere occurs (Savenije, 1995; Van der Ent and Savenije, 2011).

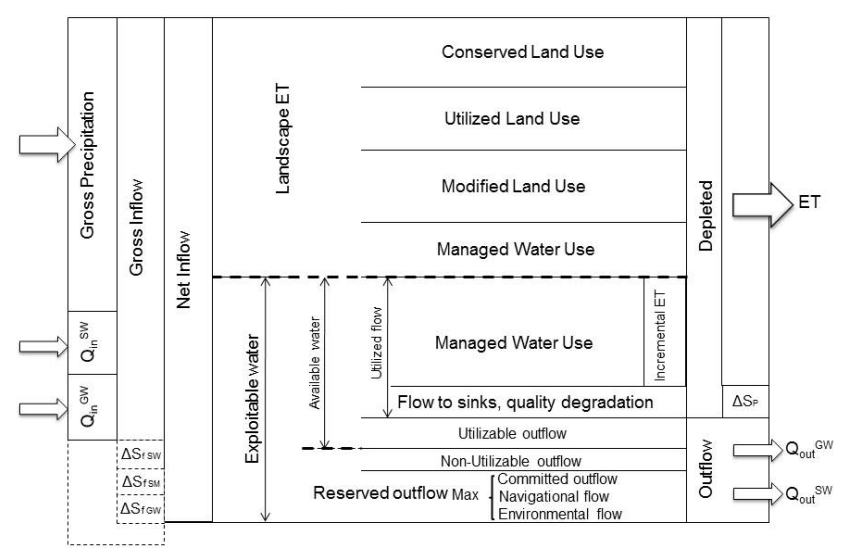

Fig. 2. Schematic presentation of the resource base sheet.

The net inflow minus landscape ET can be referred to as exploitable water. It represents the portion of the net inflow that is not evaporated and is available for downstream use and withdrawals. The exploitable water in this framework is analogous to blue water concept defined by Falkenmark and Rockström (2006). For the sake of simplicity, the resource base sheet does not distinguish between surface and groundwater in the exploitable water. The latter will be taken care of by the withdrawal sheet.

The landscape ET is further divided into the four land use categories "conserved land use", "utilised land use", "modified land use", and "managed water use". The portion of managed water use that falls under landscape ET represents evapotranspiration that originates from precipitation over this particular land use category $\left(\mathrm{ET}_{\text {prec }}\right.$ in Fig. 1). Irrigated land for instance does receive rainfall, but insufficient for crop production.

Not all of the exploitable water is available for use as part of it has to be reserved to meet downstream water right requirements (committed outflow, navigational flow and environmental flow). Guidelines for environmental flow are provided by for instance Smakhtin et al. (2004a, b). This water is called reserved outflow and is equal to the maximum of committed outflows, navigational flow and environmental flow. Note that committed outflow can also be related to groundwater, for instance for keeping Groundwater Dependent Ecosystems (GDE) healthy that tap water from the same aquifer, but are located in a downstream river basin. None of these actually deplete water; the same water that serves navigational needs may serve environmental flow demand and then flow out to meet any downstream water commitment. Non-utilisable flow mostly arises during and after flood events when excess water threatens to inundate large areas which then need to be evacuated. It could partially be committed to outflow, but the volume and timing will most likely not match the reserved outflows requirements and is, therefore, presented separately. 
Table 2. Categories of land use classes with similarity in ecosystem services, provisioning services, human interaction and interventions in the hydrological cycle. These classes form the basis for management options in WA+.

\begin{tabular}{llll}
\hline Conserved land use & Utilised land use & Modified land use & Managed water use \\
\hline Reserves or national parks & Closed natural forests & Plantation trees & Irrigated pastures \\
Areas set aside for conservation & Tropical rain forest & Rainfed pastures & Irrigated crops \\
Glaciers & Open natural forest & Rainfed crops & Irrigated fruits \\
Coastal protection sites & Woody savanna & Rainfed fruit & Irrigated biofuels \\
& Open savanna & Rainfed biofuels & Reservoirs \& canals \\
& Sparse savanna & Rainfed recreational parks & Greenhouses \\
& Shrub land & Fallow land & Aquaculture \\
& Natural pastures & Dump sites & Residential areas \& homesteads \\
& Deserts & Oasis \& wadis & Industrial areas \\
& Mountains & Roads and lanes & Irrigated recreational parks \\
& Rocks & Peri-urban areas & Managed wetlands \& swamps \\
& Flood plains & & Inundation areas \\
& Tidal flats & Mining \\
& Bare land & & Evaporation ponds \\
& Waste land & & Waste water treatment beds \\
& Moore fields & & Power plants \\
& Wetlands \& swamps & & \\
Alien invasive species & & \\
Permafrosts & & \\
& &
\end{tabular}

Exploitable water less reserved outflows is available water. It is the available water that can be allocated to various water use sectors. Part of the available water is depleted. This depleted water is called utilised flow and mainly takes place through incremental ET, but it also includes the water that flows to sinks (e.g., flows to saline groundwater aquifers or other locations where the water is not recovered) or becomes unavailable for further use due to contamination, pollution and any quality degradation because of a lack of treatment plants or beds. The available water less the utilised water is utilisable water representing the amount of additional water that could be utilised. It represents the water that is not depleted, nor reserved, and is, thus, available for use within the basin or for export and intra basin water transfers. The resource base sheet can be applied at different time scales.

Depleted water is total ET plus flows to $\operatorname{sink}\left(\Delta S_{\mathrm{p}}\right)$ which is the water that flows to sinks or become unfit for use quality wise; for instance deep percolated irrigation water that ends up in saline groundwater aquifers. Outflows refer to the amount of water that physically leaves the basin through surface water system $\left(Q_{\mathrm{out}}^{\mathrm{SW}}\right)$ and through subsurface system $\left(Q_{\mathrm{out}}^{\mathrm{GW}}\right)$. Appendix A summarises the $\mathrm{WA}+$ definitions.

\subsubsection{Performance indicators for resource base sheet}

The resource base sheet in WA+ has a set of minimum performance indicators that are presented as fractions. These indicators are to help basin planners to understand the key information on water management in a basin, or any domain that water accounts are provided for. Time series of these indicators reveal trends. The impact of water policy inter- ventions on water scarcity and benefits from water can be quantified.

Exploitable water fraction is that part of the net inflow that is not lost to the landscape ET processes. The fraction relates to total run-off generated in a river basin and also exploited water from fresh water storage.

Exploitable water $_{\text {fraction }}=\frac{\text { Exploitable water }}{\text { Net inflow }}$

Storage change fraction defines the degree of dependency on fresh storage change $\left(\Delta S_{\mathrm{fw}}\right)$. The fresh water resources are surface water storage, groundwater storage and total water storage. The negative values indicate storage depletion while positive values indicate that in the accounting period water storage has been increased in the domain.

Storage change $\mathrm{fraction}=\frac{\Delta S_{\mathrm{fw}}}{\text { Exploitable water }}$

Available water fraction relates available water to exploitable water. It describes the portion of exploitable water that is actually available for withdrawals within a basin.

Available water fraction $=\frac{\text { Available water }}{\text { Exploitable water }}$

Basin closure fraction describes to what extent available water is already depleted in a basin or domain. A closed basin is one where all available water is depleted. According to this definition a closed basin can still have substantial discharge in case all outflow is reserved (Molden et al., 2003).

Basin $_{\text {closure }}$ fraction $=\frac{\text { Utilised flow }}{\text { Available water }}$ 
Reserved outflows fraction relates the reserved outflows to outflow via streams and aquifers. It indicates whether the committed outflows are being met. The reserved outflows are intended to surface and groundwater outflow.

Reserved outflows fraction $=\frac{\text { Reserved outflows }}{Q_{\text {out }}^{\mathrm{SW}}+Q_{\mathrm{out}}^{\mathrm{GW}}}$

\subsection{WA+ evapotranspiration sheet}

The evapotranspiration sheet (Fig. 3) describes which parts of ET processes are managed, manageable or nonmanageable. The term manageable implies that it is not actively managed yet, and that a light form of utilisation is accepted under the current situation. Knowing the physical volumes of ET by different users, the next step is to evaluate the benefits derived from the use of water. It requires a value judgment to define beneficial and non-beneficial ET. The definition of "beneficial" and "non-beneficial" ET can be adjusted in specific cases by the users based on their local value assessment.

Non-beneficial ET occurs through certain physical processes: evaporation (from soil, water), and interception evaporation from wet leaves and canopies (Rutter et al., 1971; Savenije, 2004) and wet surfaces (e.g., buildings, roads). However, in some cases interception evaporation is important for temperature regulation of plants and, hence, is beneficial. Transpiration $(T)$ is the transfer of water by the plant to the atmosphere through stomata in the leaves. Water vapour transfer via transpiration and $\mathrm{CO}_{2}$ inhalation are biophysically linked (e.g., Monteith, 1988). While $T$ is generally considered as beneficial, it can be considered non-beneficial in some cases such as weed infestations in cropland or in degraded landscapes, or when there are non-desirable plants. Alien invasive species are considered as highly undesirable and distorting sensitive balances between rainfall and ET. Countries such as South Africa and Australia have active programmes to clear large areas of alien invasive. This exemplifies that definition of "beneficial" or "non-beneficial" depends on a value assessment.

$E$ is usually considered as non-beneficial because the vast majority of $E$ originates from wet soils that are fallow or covered partially (Choudhury et al., 1998). However, the $E$ from natural water surfaces is often beneficial, for example in cases where water bodies serve the purpose of fishing, aquatic birds, buffering floods, water sports, leisure, etc. The WA+ evapotranspiration sheet is shown in Fig. 3. It reports on the breakdown of ET into $E, T$ and interception and defines which portion of ET is beneficial and which nonbeneficial.

\subsubsection{Performance indicators for the evapotranspiration sheet}

Performance indicators for the WA+ evapotranspiration sheet provide key information on the magnitude of benefi-

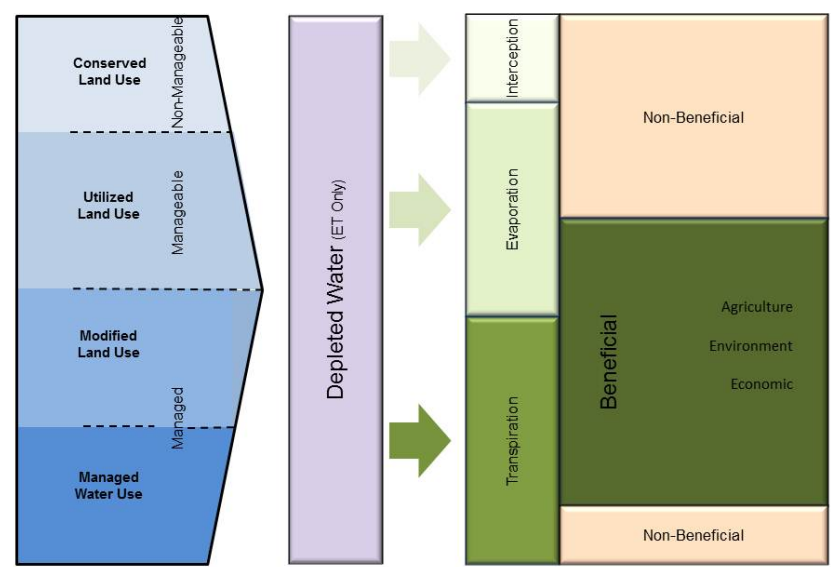

Fig. 3. Schematic presentation of the evapotranspiration sheet.

cial ET in a basin. Water used by key water users in a basin is expressed in terms of fractions.

Transpiration fraction is the part of ET that is transpired by plants and it reflects an impact on bio-physical process in water scarce basins.

Transpiration $_{\text {fraction }}=\frac{T}{\mathrm{ET}}$

Beneficial ET fraction relates beneficial $E$ and $T$ to the total ET in a basin.

Beneficial $_{\text {fraction }}=\frac{\text { E beneficial }+\mathrm{T} \text { beneficial }}{\mathrm{ET}}$

Managed ET fraction indicates the ET processes in a basin that could be manipulated by land use, cultivation practices and water withdrawals.

Managed $_{\text {fraction }}=\frac{\text { ET managed }}{\text { ET }}$

Agricultural ET fraction is the part of ET attributable to the agricultural production.

Agricultural $\mathrm{ET}_{\text {fraction }}=\frac{\text { Agricultural ET }}{\mathrm{ET}}$

Irrigated ET fraction describes the portion of agricultural ET that is related to irrigated agriculture.

Irrigated $\mathrm{ET}_{\text {fraction }}=\frac{\text { irrigated agricultural ET }}{\text { Agricultural ET }}$

\subsection{WA+ productivity sheet}

The WA+ productivity sheet is meant to describe the agricultural production per unit of water (Kijne et al., 2003; Zwart et al., 2010) and is illustrated in Fig. 4. The sheet reports on the bio-physical land productivity $\left(\mathrm{kg} \mathrm{ha}^{-1}\right)$ and water productivity $\left(\mathrm{kg} \mathrm{m}^{-3}\right)$ in the WA+'s four land categories. Economic dimensions such as proposed by Hellegers et al. (2009) are 


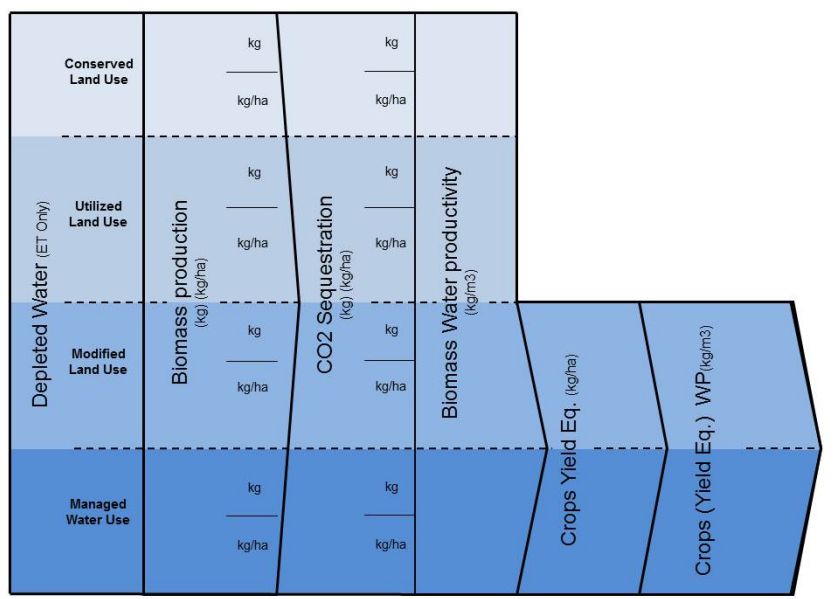

Fig. 4. The WA+ productivity sheet.

for the sake of simplicity excluded. Productivity measurement in WA+ is based on biomass production. Biomass production is a consequence of plant photosynthesis and is the primary foundation for food, feed, fibre, shelter, biodiversity and carbon storage. Biomass production results from carbon assimilation processes through which $\mathrm{CO}_{2}$ from the atmosphere is absorbed through photosynthesis, and stored as carbon in biomass, both above ground and below ground. Carbon sequestration is gaining more attention as an opportunity to stabilise $\mathrm{CO}_{2}$ levels in the atmosphere and to mitigate climate change impacts (Gibbs and Herold, 2007). Several studies provide spatial databases that estimate global vegetation carbon stocks (Olson et al., 1985; Gibbs, 2006). Ruesch and Gibbs (2008) have produced a global biomass carbon map for 2000 based on the GLC2000 land use map.

The WA+ productivity assessment, given the importance of the subject, encompasses figures for $\mathrm{CO}_{2}$ sequestration by different land uses alongside biomass production. Crop and pasture biomass production can be translated to equivalent yields by using harvest indexes and then to the water productivity by using ET figures.

\subsubsection{Performance indicators for the productivity sheet}

The WA+ productivity sheet's performance indicators have been formulated to indicate the state of a basin in terms of land productivity and water productivity. This is translated into food security conditions and carbon sequestration.

Land productivity indicators relate biomass production and yield equivalent of crops to unit of land in the period of accounting in terms of $\mathrm{kg}$ per ha.

Land productivity ${ }_{\text {crops }}$

$=\frac{\text { Crops biomass production } * \text { harvest Index }}{\text { Cropped area }}$
Land productivity $_{\text {pasture }}$

$=\frac{\text { Pasture biomass production } * \text { harvest Index }}{\text { Pasture area }}$

Water productivity indicators report on the physical mass of production per unit volume of water consumed in terms of kg per $\mathrm{m}^{3}$.

Water productivity crops rainfed $_{\text {. }}$

$=\frac{\text { Rainfed crops biomass production } * \text { Harvest index }}{\text { Rainfed crops ET }}$

Water productivity $_{\text {crops irrigated }}$

$=\frac{\text { Irrigated crops biomass production } * \text { Harvest index }}{\text { Irrigated crops ET }}$

Overall land and water productivity of crops and pasture can be further broken down into rainfed and irrigated land systems. This will provide productivity figures for rainfed and irrigated land separately.

Food-irrigation dependency $=\frac{\text { Irrigated flood production }}{\text { Total food production }}$

\subsection{WA+ withdrawal sheet}

The withdrawal sheet has several common elements with the existing UN water accounting procedure that is merely based on allocations and withdrawals. Despite the fact that the resource base sheet avoids complex hydrological processes that requires groundwater and surface water use to be quantified specifically, it is of utmost relevance to discern between surface and groundwater systems. The main reason is that their management options are quite different; surface water can be used, for example, for hydropower, while groundwater is more suited for domestic drinking water and is a choice of preference for many farmers. Most excess water flows to surface water systems, and this water is easier to regulate and manage than groundwater systems.

As opposed to surface water systems, groundwater resources are accessible rather instantly without passing through conveyance networks and contain water throughout the entire year. As a result this flexibility has enhanced the extraction of groundwater for irrigated crops (Qureshi et al., 2010) and other purposes. Thus, considering the importance of groundwater, and the different management opportunities as compared to surface water systems, it is imperative to separate surface and groundwater systems in WA + . An example of an accounting system for groundwater is given by Foster et al. (2009) and Foster and Perry (2010).

The aim of the WA+ withdrawals sheet is to provide an explicit picture of flows in the Managed Water Use category. Typical water users are reservoirs, irrigated agriculture, aquaculture, domestic use and industries. Incremental ET from reservoirs mostly takes the form of evaporation from free water surfaces. The withdrawal sheet diagram is displayed 


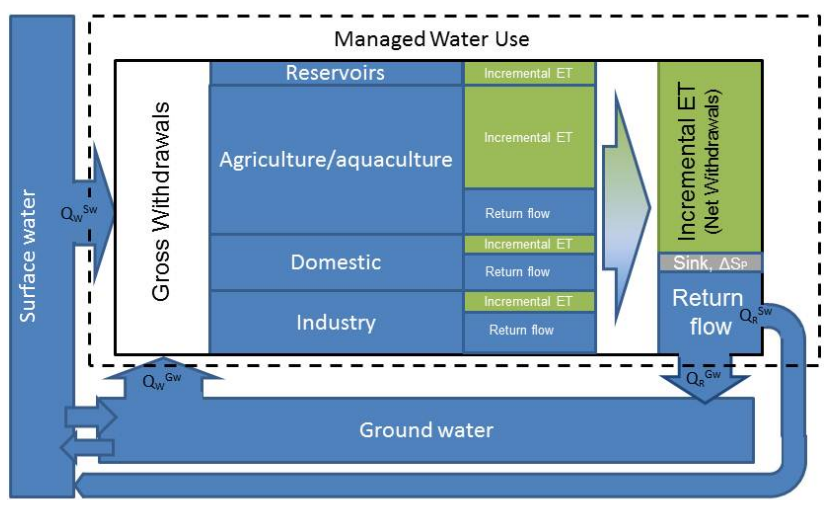

Fig. 5. Schematic presentation of withdrawal sheet.

in Fig. 5. Fresh water is drawn from surface and groundwater resources, $Q_{\mathrm{w}}^{\mathrm{SW}}$ and $Q_{\mathrm{w}}^{\mathrm{GW}}$, for different uses. Part of the withdrawn water is consumed as incremental $\mathrm{ET}\left(\mathrm{ET}_{\mathrm{Q}}\right)$ and the rest returns to the surface and groundwater sources, $Q_{\mathrm{R}}^{\mathrm{SW}}$ and $Q_{\mathrm{R}}^{\mathrm{GW}}$. Groundwater withdrawals for drinking water supply can after water treatment be discharged into rivers, hence, surface water and groundwater can interact in the withdrawal sheet.

\subsubsection{Performance indicators for the withdrawal sheet}

Information presented in the WA+ withdrawal sheet can be essential for estimating the impact of some widely supported solutions in water scarce environments, including efficiency improvements, capturing recoverable flows and groundwater quota. Given the importance of these concepts the performance indicators defined for this sheet include the following:

The Groundwater withdrawal fraction indicator provides information related to the extent that a basin is reliant on groundwater resources for development.

Groundwater withdrawal fraction $=\frac{Q_{\mathrm{w}}^{\mathrm{GW}}}{Q_{\mathrm{w}}^{\mathrm{SW}}+Q_{\mathrm{w}}^{\mathrm{GW}}}$

Classical irrigation efficiency (CE) follows the concept of Israelsen (1932) and Jensen et al. (1967) as presented by Seckler et al. (2003). It is defined as the net evapotranspiration (incremental ET in our terminology) divided by the amount of water withdrawals.

$\mathrm{CE}=\frac{\text { incremental } \mathrm{ET} \text { irrigated agriculture }\left(\mathrm{ET}_{\mathrm{Q}}\right)}{Q_{\mathrm{W}}(\text { Irrigated agriculture })}$

Recoverable fraction indicates the proportion of water withdrawal that is not consumed and, thus, returns to surface and groundwater system. It relates to the definition of recoverable flows presented by ICID (Perry, 2007)

Recoverable fraction $=\frac{Q_{\mathrm{R}}}{Q_{\mathrm{W}}}$

$\mathrm{WA}+$ indicators have been formulated to serve various policy objectives. They cover a broad spectrum of indices related to water resource management, water-ecosystem sustainability and food security. WA+ users (e.g., policy makers) can, therefore, pick and focus on the indicators that they perceive to be relevant to their purpose of the accounting exercise.

\section{Satellite data measurements}

Collection of data from various sources and institutes to feed WA+ is a rather challenging task and is currently the largest obstacle for water accounting in an operational context. While rainfall can be measured relatively simply with gauges (not being free from errors), ET can be measured with advanced instruments only (Twine et al., 2000; Teixeira and Bastiaanssen, 2010). It is a general misconception that ET can be measured by routine weather stations. Hydrometeorological observatories are available, but only at selected locations in river basins. Maintenance of the hydrometeorological observation is not straightforward. So large components of the basin water flows are not measured and are at best difficult to measure in situ. The input data into $\mathrm{WA}+$, therefore, has to be based upon satellite measurements and alternatively from hydrological models.

Except for the withdrawal sheet that is more related to the classical water accounting processes, the input data for the other WA+ sheets can mostly be estimated through satellite measurements. Basin outflow and inter-basin transfer flows need at all times to be measured. Remote-sensing techniques ensure access to spatial data, and make it possible to apply the framework to all ungauged or poorly gauged basins. Another benefit of using remote sensing is the low cost of acquiring data and the immediate availability of data. Measuring ground data and collecting data through surveys often requires significant manpower to collect and interpret the data. Remote-sensing analysis can be done relatively quickly and cheaply. Ground data are, however, useful and can complement and refine the space-borne data sets. The number of earth observation satellites is growing fast, and the databases emerging from these spatial measurements show the same evolving trend. Land use, rainfall, ET, soil moisture, biomass production can all be retrieved from raw satellite measurements, provided that the proper interpretation algorithms are used. Remote-sensing techniques, also, can be employed to separate ET into $E$ and $T$ through using two-layer energy balance models. This is rather commonly applied in land surface models (e.g., Shuttleworth and Wallace, 1985). The basis for distinguishing $T$ from $E$ is the partitioning of net radiation into a component related to canopies and another component related to soil. A second major aspect is that $T$ is controlled by soil moisture in the rootzone and $E$ by moisture in the topsoil. Satellite radar altimetry and laser altimetry (i.e., ICESat) can be used successfully to derive water levels of inland water bodies (e.g., Calmant et al., 2008) and changes of total water storage can be estimated 
by gravitational satellites such as the Gravity Recovery and Climate Experiment (GRACE). The accuracy of determining important hydrological processes and water management aspects is acceptable, and it becomes an attractive alternative to conventional data sources (Bastiaanssen, 1998; Schultz and Engman, 2000; Schmugge et al., 2002). It goes beyond the scope of the current paper to discuss in detail the recent advances in earth observations.

\section{Limitations/cautions}

The WA+ is a comprehensive tool for assessing water depletion and productivity in a basin in relation to land use, but it has its own limitations. The main limitation is that the $\mathrm{WA}+$ cannot replace hydrological models in their function to provide detailed information on water flows in a basin. WA+ summarises water depletion in a basin, rather than analysing flow from one location to another. All rivers and tributaries are regarded as being one single bulk river and all the aquifers as one single bulk aquifer. An overall basin account can, however, be an aggregation of sub-accounts for different geographic elements. WA+ can be envisaged as a display of hydrological modelling results, in a standardised manner that can be understood by a large society of water professionals.

All satellite data parameters have some level of uncertainty and error that needs to be taken into account because satellites are measuring hydrological processes indirectly. The errors in large water volumes (i.e., rainfall and ET) may result in large errors in river and aquifer flows. More research is required to understand the impact of these uncertainties in the WA+ outputs.

The accounting period for WA+ is normally one year. However, seasonal and annual variations have impacts on basin water flows. For instance, water deficits in the dry season if followed by a wet season, might be overlooked when compiling annual bulk figures. The WA+ framework is applicable to shorter periods if detailed data on storage changes (i.e., surface and groundwater storage and soil moisture) are available for the beginning and the end of each accounting period.

$\mathrm{WA}+$ only provides tentative guidelines for beneficial and non-beneficial depletion, and the user needs to define them based on a personal value assessment. One example of the complexity of the issue is the presence of floodplains. While flood plains and green corridors along rivers can be considered for contributing to ecosystem services, the incremental ET due to flooding could reduce the river flow to downstream countries beyond the committed minimum flow. Value assessment is needed to make good use of the WA+ analytical framework, and this can be achieved by prescribing beneficial and non-beneficial depletion by land use type. Economic, environmental, social and other benefits could be specified in detail.
Surface and groundwater systems are fundamental for development of water resources and basin management plans. The partitioning of surface/groundwater recharge and their successive gross withdrawals are considered in the WA+ withdrawal sheet. Although we have no operational system in place to quantify these flows, it is essential to recognise this in the WA+ framework. While incremental ET can be assessed in the resource base and withdrawal sheets, more scientific rigor is needed to develop a generic solution for determining the incremental ET from total ET and effective rainfall.

\section{Summary and conclusions}

WA+ provides an analytical framework that summarises water resources conditions and management in complex river basins. The WA+ framework goes beyond accounting of surface water flows and their withdrawals as in most reporting systems to basin authorities and national governments. The innovative character of WA+ is the incorporation of comprehensive watershed processes, the role of land use, explicit recognition of manageable flows, description of utilised flow, difference between gross and net withdrawals, reserved outflows and the benefits resulting from water depletion processes in terms of biomass production, carbon sequestration, among others. The availability of a standard set of indicators based on transparent data collection procedures is beneficial for discussions on water resources management solutions and the water policy decision making processes.

Water accounting starts with precipitation and changes in storage of surface water, groundwater and snow packs to arrive at net inflow. WA+ reports on water depletion in a basin using spatially distributed evapotranspiration rates, and assesses which part is depleted in the landscape after rainfall and which part is depleted due to withdrawals. The available water for withdrawals is further subdivided into utilised flows and utilisable outflows. Utilised flow is expressed as an incremental ET complemented by $\Delta S_{\mathrm{p}}$. A large portion of the gross withdrawals - that are difficult to measure - are recycled and re-used in downstream areas, thus, being even more difficult to measure. This makes gross withdrawals of less interest as compared to incremental ET. The outflow from the basin is compared to reserved outflows. Within WA+, knowledge of production outputs such as biomass production, food production and carbon sequestration in various land use categories is related to water depletion. This is the key to benchmarking and increasing the productivity of water. WA+ is offering a set of default performance indicators. Users can add extra indicators according to their specific interest.

WA+ uses accessible satellite measurements as its main input data source, instead of detailed hydro-meteorological measurements. This independence makes it feasible to apply WA+ basically everywhere, and by doing so, to get a clearer 
understanding of the national, continental and global scale status of water resources.

The WA+ framework provides strategic insights in the possibilities to secure water resources availability and resilience to droughts and climate change, while maintaining biodiversity, preventing land degradation and conserving water for committed outflow. The WA+ framework evaluates the impact of interventions such as (i) water re-allocations, (ii) reduced groundwater withdrawals, (iii) deficit irrigation, (iv) modernisation of irrigation, (v) artificial recharge, (vi) water retention and storage, (vii) waste water treatment, (viii) water productivity improvement, (ix) urban expansion, (x) deforestation, (xi) introduction of biofuel crops, (xii) cropping pattern change, (xiii) altered cultivation practices, etc. The framework has a simple presentation by means of four sheets, and is easy to implement and understand. Communications and decision making has the potential to improve, provided that the framework is supported by larger international academic and donor organisations. Dissemination of the WA+ principles to the responsible water professionals is also an elementary prerequisite for making the framework commonly known.

The renewed WA+ framework is, for all above mentioned reasons, an elegant and valuable tool for water resource planning and development, particularly, in ungauged basins and internationally disputed water flows with millions of people where the available water resources has started to decline at an alarming rate and the knowledge base is poor.

\section{Appendix A}

\section{Definitions WA+}

Gross inflow is the total amount of water that flows into the domain, including precipitation plus any inflow from surface or ground water sources.

Net inflow is the gross inflow after correction of storage change $(\Delta S)$ and represents water available for landscape ET and exploitable water.

Landscape ET is the water that evapotranspires directly from the natural water cycle without artificial supply.

Exploitable water represents water being present in reservoirs, rivers, lakes and groundwater that is used for utilised, utilisable, non-utilisable and reserved outflows.

Reserved outflow is the water that has to be reserved to meet the committed outflow, navigational flows and environmental flow.

Available water is the exploitable water minus reserved outflows and non-utilisable outflow. It represent the water that is available for use at the domain.

Utilised flow is the part of available water that is depleted for uses.
Utilisable outflow is the available water for resources development.

Conserved land use relates to the environmentally sensitive land uses and natural ecosystem that is set aside for protection, including protection from sea.

Utilised land use represents a low to moderate resource utilisation, such as savannah, woodland and mixed pastures. Modified land use relates to the replacement of the original vegetation for increased utilisation of land resources.

Managed water use represents landscape elements that receive withdrawals from utilised flows.

Acknowledgements. Funds for this research were provided by the Capacity Building Programme of the International Water Management Institute (IWMI) through the CGIAR Research Programme on Water Land and Ecosystems. The authors are thankful to Chris Perry and Mac Kirby (CSIRO) for the thorough and constructive review. Yasir Mohamed (UNESCO-IHE), Vladimir Smakthin (IWMI) and Peter Droogers (FutureWater) are acknowledged for their valuable discussions on the framework.

Edited by: P. van der Zaag

\section{References}

Anderson, M. C., Allen, R. G., Morse, A., and Kustas, W. P.: Use of Landsat thermal imagery in monitoring evapotranspiration and managing water resources, Remote Sens. Environ., 122, 50-65, doi:10.1016/j.rse.2011.08.025, 2012.

Alcamo, J., Florke, M., and Marker, M.: Future long-term changes in global water resources driven by socio-economic and climatic changes, Hydrol. Sci. J., 52, 247-275, 2007.

Allen, R. G., Pereira, L. S., Raes, D., and Smith, M.: Crop Evapotranspiration: Guidelines for Computing Crop Water Requirements, FAO Irrigation and Drainage Paper, Rome, 56, 1998.

Amarasinghe, U. A., Shah, T., Turral, H., and Anand, B. K.: India's Water Future to 2025-2050: Business-as-Usual Scenario and Deviations, IWMI Research Report 123, International Water Management Institute, Colombo, Sri Lanka, 2007.

Australian Bureau of Statistics (ABS): Water Account, Australia 2000-01, Australian Bureau of Statistics, Canberra, 2004.

Australian Bureau of Statistics (ABS): Water Account, Australia 2004-05, Australian Bureau of Statistics, Canberra, 2006.

Bastiaanssen, W. G. M.: Remote sensing in water resources management: the state of the art, International Water Management Institute, Colombo, Sri Lanka, 1998.

Bastiaanssen, W. G. M. and Chandrapala, L.: Water balance variability across Sri Lanka for assessing agricultural and environmental water use, Agr. Water Manage., 58, 171-192, 2003.

Bhattarai, M., Pant, D., Mishra, V. S., Devkota, H., Pun, S., Kayastha, R. N., and Molden, D.: Integrated development and management of water resources for productive and equitable use in the Indrawati River Basin, Nepal, IWMI Working Paper 41, International Water Management Institute Colombo, Sri Lanka, 2002.

Bicheron, P., Leroy, M., Brockmann, C., Krämer, U., Miras, B., Huc, M., Niño, F., Defourny, P., Vancutsem, C., Arino, O., 
Ranera, F., Petit, D., Amberg, V., Berthelot, B., and Gross, D.: Globcover: a $300 \mathrm{~m}$ global land cover product for 2005 using ENVISAT MERIS time series, in Proceeding of the Second International Symposium on Recent Advances in Quantitative Remote Sensing, edited by: Sobrino, J. A., Servicio de Publicaciones. Universitat de Valencia, Valencia, Spain, 2006.

Biggs, T., Gaur, A., Scott, C., Thenkabil, P., Rao, P. G., Gumma, M. K., Acharya, S., and Turral, H.: Closing of the Krishna Basin: Irrigation development, stream flow depletion, and macro scale hydrology, IWMI Research Report 111, International Water Management Institute, Colombo, Sri Lanka, 2007.

Calmant, S., Seyler, F., and Crétaux, J. F.: Monitoring continental surface waters by satellite altimetry, Surv. Geophys., 29, 247269, 2008.

Cheema, M. J. M. and Bastiaanssen, W. G. M.: Land use and land cover classification in the irrigated Indus Basin using growth phenology information from satellite data to support water management analysis, Agr. Water Manage., 97, 1541-1552, 2010.

Choudhury, B. J., Digirolamo, N. E., Susskind, J., Darnell, W. L., Gupta, S. K., and Asrar, G.: A biophysical process-based estimate of global land surface evaporation using satellite and ancillary data, II, Regional and global patterns of seasonal and annual variations, J. Hydrol., 205, 186-204, 1998.

de Vries, M. E., Rodenburg, J., Bado, B. V., Sow, A., Leffelaar, P. A., and Giller, K. E.: Rice production with less irrigation water is possible in a Sahelian environment, Field Crop. Res., 116, 154164, 2010.

Dong, B., Molden, D., Loeve, R., Li, Y. H., Chen, C. D., and Wang, J. Z.: Farm level practices and water productivity in Zhanghe Irrigation System, Paddy Water Environment, 2, 217-226, 2004.

Falkenmark, M. and Rockström, J.: The new blue and green water paradigm: Breaking new ground for water resources planning and management, J. Water Resour. Plann. Manage., 132, 129133, 2006

FAO: Coping with water scarcity; an action framework for agriculture and food security, FAO water reports 38, FAO, Rome, 2012.

Foster, S. and Perry, C.: Improving groundwater resource accounting in irrigated areas: a prerequisite for promoting sustainable use, J. Hydrogeol., 18, 291-294, 2010.

Foster, S., Perry, C., Hirata, R., and Garduno, H.: Groundwater resource accounting: critical for effective management in a "changing world", GW-MATE Case Profile 16, the World Bank, Washington, D.C., 2009.

Gibbs, H. K.: Olson's major world ecosystem complexes ranked by carbon in live vegetation: an updated database using the GLC2000 land cover product (NDP-017b), ORNL-CDIAC, 2006.

Gibbs, H. K. and Herold, M.: Tropical deforestation and greenhouse gas emissions, Environ. Res. Lett., 2, 045021, doi:10.1088/17489326/2/4/045021, 2007.

Gleick, P. H.: The changing water paradigm: A look at twenty-first century water resources development, Water Int., 25, 127-138, 2000.

Hellegers, P. J., Soppe, R., Perry, C. J., and Bastiaanssen, W. G. M.: Combining remote sensing and economic analysis to support decisions that affect water productivity, Irrig. Sci., 27, 243-251, 2009.

Israelsen, O. W.: Irrigation Principles and Practices, John Wiley, New York, 1932.
Jensen, M. E., Swarner, L. R., and Phelan, J. T.: Improving Irrigation Efficiencies, in Irrigation of Agricultural Lands, Agronomy Series, 11, American Society of Agronomy, Wisconsin, USA, 1967.

Karimi, P., Molden, D., Bastiaanssen, W. G. M., and Cai, X.: Water accounting to assess use and productivity of water - evolution of the concept and new frontiers, in: Water accounting: international approaches to policy and decision-making, edited by: Chalmers, K. and Godfrey, J., Chapter 4, Edgar Elger, Cheltenham, UK, 76-88, 2012.

Karimi, P., Bastiaanssen, W. G. M., Molden, D., and Cheema, M. J. M.: Basin-wide water accounting using remote sensing data: the case of transboundary Indus Basin, Hydrol. Earth Syst. Sci., 17, 2473-2486, doi:10.5194/hess-17-2473-2013, 2013.

Kijne, J. W., Barker, R., and Molden, D.: Comprehensive Assessment of Water Management in Agriculture, CABI Publishing in association with International Water Management Institute, UK, 2003.

Loeve, R., Molden, D., Dong, B., Li, Y. H., Chen, C. D., and Wang, J. Z.: Issues of scale in water productivity in the Zhang He irrigation system: Implications for irrigation in the basin context, Paddy Water Environ., 2, 227-236, 2004.

Loveland, T. R., Reed, B. C., Brown, J. F., Ohlen, D. O., Zhu, Z., Yang, L., and Merchant J. W.: Development of a global land cover characteristics database and IGBP DISCover from $1 \mathrm{~km}$ AVHRR data, Int. J. Remote Sens., 21, 1303-1330, 2000.

Molden, D.: Accounting for water use and productivity, SWIM Paper 1, International Irrigation Management Institute, Colombo, Sri Lanka, 1997.

Molden, D.: Water for Food, Water for Life: A Comprehensive assessment of water management in agriculture, Earthscan, London, 2007.

Molden, D. and Sakthivadivel, R.: Water accounting to assess use and productivity of water, Water Resour. Develop., 15, 55-71, 1999.

Molden, D., Murray-Rust, H., Sakthivadivel, R., and Makin, I.: A water productivity framework for understanding and action, in: Water Productivity in Agriculture: Limits and Opportunities for Improvement, edited by: Kijne, J. W., Barker, R., and Molden, D., Comprehensive Assessment of Water Management in Agriculture, CABI Publishing in association with International Water Management Institute, UK, 1-18, 2003.

Molden, D., El Kady, M., and Zhu, Z.: Use and productivity of Egypt's Nile, paper presented at the14th Technical Conference on Irrigation, Drainage and Flood Control, USCID, Phoenix, Arizona, 1998.

Molle, F. and Wester, P.: River basin trajectories: An inquiry into changing waterscape, in: River basin trajectories, societies, environments and development, edited by: Molle, F. and Wester, P., Comprehensive assessment of management in agriculture series, Colombo, Sri Lanka, 8, 1-19, 2009.

Monteith, J. L.: Does transpiration limit the growth of vegetation or vice versa?, J. Hydrol., 100, 57-68, 1988.

Olson, J. S., Watts, J. A., and Allison, L. J.: Major world ecosystem complexes ranked by carbon in live vegetation: A Database. NDP-017, Carbon Dioxide Information Center, Oak Ridge National Laboratory, Oak Ridge, Tennessee, doi:10.3334/CDIAC/lue.ndp017, (Revised 2001), 1985. 
Perry, C. J.: Efficient irrigation; inefficient communication; flawed recommendations, Irrig. Drainage, 56, 367-378, 2007.

Perry, C. J.: Accounting for water; stocks, flows, and values, in Inclusive wealth report 2012 measuring progress toward sustainability, UNU-IHPD and UNEP, Cambridge University Press, Cambridge, 215-230, 2012.

Perry, C. J. and Bucknall, J.: Water resource assessment in the Arab world: new analytical tools for new challenges, in: Water in the Arab World: Management Perspective and Innovations, edited by: Jagannathan, N. J., Mohamed, A. S., and Kremer, A., The World Bank, Washington D.C., 2009.

Qureshi, A. S., Gill, M. A., and Sarwar, A.: Sustainable groundwater management in Pakistan: challenges and opportunities, Irrig. Drainage, 59, 107-116, doi: 10.1002/ird.455, 2010.

Rockström, J. and Gordon, L.: Assessment of green water flows to sustain major biomes of the world: Implications for future ecohydrological landscape management, Phys. Chem. Earth Part B, 26, 843-851, 2001.

Rockström, J., Steffen, W., Noone, K., Persson, A., Chapin, F. S., Lambin, E. F., Lenton, T. M., Scheffer, M., Folke, C., and Schellnhuber, H. J.: A safe operating space for humanity, Nature, 461, 472-475, 2009.

Ruesch, A. and Gibbs, H. K.: New IPCC Tier-1 Global Biomass Carbon Map For the Year 2000, Oak Ridge National Laboratory, Oak Ridge, Tennessee, 2008.

Rutter, A. J., Kershaw, K. A., Robins, P. C., and Morton, A. J.: A predictive model of rainfall interception in forests. I: Derivation of the model from observations in a plantation of Corsican pine, Agric. Meteorol., 9, 367-384, 1971.

Savenije, H. H. G.: New definitions for moisture recycling and the relationship with land-use changes in the Sahel, J. Hydrol., 167, 57-78, 1995.

Savenije, H. H. G.: The importance of interception and why we should delete the term evapotranspiration from our vocabulary, Hydrolog. Process., 18, 1507-1511, 2004.

Schmugge, T. J., Kustas, W. P., Ritchy, J. C., Jackson, T. J., and Rango, A.: Remote sensing in hydrology, Adv. Water Resour., 25, 1367-1385, 2002.

Schultz, G. A. and Engman, E. T.: Present use and future perspectives of remote sensing in hydrology and water management, IAHSAISH Publ. 267, 545-55, IAHS, Wallingford, UK, 2000.

Seckler, D.: The new era of water resources management: From "dry" to "wet" water savings, International Water Management Institute, Colombo, Sri Lanka, 1996.

Seckler, D., Molden, D., and Sakthivadivel, R.: The concept of efficiency in water resources management and policy, in water Productivity in agriculture: Limits and opportunities for improvement, edited by: Kijne, J. W., Barker, R., and Molden, D., 37-52, Comprehensive assessment of water management in Agriculture. CABI Publishing in association with International Water Management Institute, UK, 2003.
Shuttleworth, W. J. and Wallace, J. S.: Evaporation from sparse crops - an energy combination theory, Q. J. Roy. Meteorol. Soc., 111, 839-855, 1985.

Sivapalan, M., Takeuchi, K., Franks, S. W., Gupta, V. K., Karambiri, H., Lakshmi, V., Liang, X., McDonnell, J. J., Mendiondo, E. M., O'Connell, P. E., Oki, T., Pomeroy, J. W., Schertzer, D., Uhlenbrook, S., and Zehe, E.: IAHS Decade on Predictions in Ungauged Basins (PUB), 2003-2012: Shaping an exciting future for the hydrological sciences, Hydrol. Sci. J., 48, 857-880, 2003.

Smakhtin, V., Revenga, C., and Döll, P.: Taking into account environmental water requirements in globalscale water resources assessments, Research Report of the CGIAR Comprehensive Assessment Program of Water Use in Agriculture, International Water Management Institute, Colombo, Sri Lanka, 2004a.

Smakhtin, V., Revenga, C., and Döll, P.: A pilot global assessment of environmental water requirements and scarcity, Water Int., 29, 307-317, 2004b.

Teixeira, A. H. de C. and Bastiaanssen W. G. M.: Five methods to interpret field measurements of energy fluxes over a microsprinkler-irrigated mango orchard, Irrig. Sci., 28, 1-16, 2010.

Twine, T. E., Kustas, W. P., Norman, J. M., Cook, D. R., Houser, P. R., Meyers, T. P., Prueger, J. H., Starks, P. J., and Wesely, M. L.: Correcting eddy-covariance flux over grassland, Agr. Forest Meteorol., 103, 279-300, 2000.

UN: System of Environmental Economic Accounting for Water, United Nation Statistics Division, Geneva, 2007.

UN-Water: Coping with water scarcity - Challenge of the twentyfirst century, Un Water, Geneva, 2007.

van der Ent, R. J. and Savenije, H. H. G.: Length and time scales of atmospheric moisture recycling, Atmos. Chem. Phys., 11, 18531863, doi:10.5194/acp-11-1853-2011, 2011.

van der Zaag, P., Juizo, D., Vilanculos, A., Bolding, A., and Uiterweer, N. P.: Does the Limpopo River Basin have sufficient water for massive irrigation development in the plains of Mozambique?, Phys. Chem. Earth, Parts A/B/C, 35, 832-837, 2010.

Vorosmarty, C. J., Green, P., Salisbury, J., and Lammers, R. B.: Global water resources: vulnerability from climate change and population growth, Science, 289, 284-288, 2000.

Wallace, J. S.: Increasing agricultural water efficiency to meet future food production, Agric. Ecosyst. Environ, 82, 105-119, 2000.

Zwart, S. J., Bastiaanssen, W. G. M., de Fraiture, C., and Molden, D.: A global benchmark map of water productivity for rainfed and irrigated wheat, Agr. Water Manage., 97, 1617-1627, 2010. 